\title{
Hubungan Karakteristik Perawat terhadap Pelaksanaan Sasaran Keselamatan Pasien Pasca Akreditasi Rumah Sakit "X" di Kota Palembang Tahun 2018
}

\author{
Raden Surahmat ${ }^{1}$, Meri Neherta ${ }^{2}$, Nurariati ${ }^{3}$ \\ ${ }^{1}$ Mahasiswa Magister Keperawatan, Fakultas Keperawatan, Universitas Andalas, Padang, Sumatera Barat \\ ${ }^{2}$ Dosen Magister Keperawatan, Fakultas Keperawatan, Universitas Andalas, Padang, Sumatera Barat \\ ${ }^{3}$ Perawat Rumah Sakit Mohammad Hoesin, Palembang, Sumatera Selatan \\ Email : radensurahmat28@gmail.com, merineherta@nrs.unand.ac.id, nur ariati.mkep@yahoo.com
}

\begin{abstract}
Safety of patients, nurses, companions and visitors is the main priority of nursing services in hospitals, because quality services will have an impact on hospital accreditation assessments. This study aims to determine the relationship between the characteristics of nurses on the implementation of patient safety goals after accreditation of " $X$ " hospital in the city of Palembang in 2018. This research is descriptive using quantitative methods with sampling techniques using purposive sampling consisting of 96 nurses in 10 wards inpatient " $X$ " Hospital in Palembang city. The study was conducted from March 272018 to April 212018 using a questionnaire and was analyzed using a computer system. Based on the results of the study, it is known that the characteristics of 96 respondents with vocational education $97.9 \%$, female sex $88.6 \%$, age <35 years $51.1 \%$, working period $>2$ years $93.2 \%$, and the implementation of patient safety goals $84,1 \%$ with details of good identification accuracy $70.8 \%$, good effective communication $94.8 \%$, good drug safety $76.0 \%$, right procedure, location of patients operating both $87.5 \%$, reduction in infection risk both $50.0 \%$ and reduction in risk of patients falling well $51.0 \%$. While the results of the analysis used chi square, there was no relationship of gender, age and length of work to the implementation of patient safety goals after hospital accreditation. The implementation of patient safety goals must be carried out by all nurses in the hospital. It is expected that the hospital to build awareness of the importance of patient safety by supporting nurses in integrating activities oriented to patient safety by applying reporting systems, communicating, learning from experience and always prioritizing prevention of risks that will occur in order to improve quality services.
\end{abstract}

Keywords:

Nurses, hospitals, implementation of patient safety goals, accreditation

\section{PENDAHULUAN}

Rumah Sakit merupakan institusi pelayanan kesehatan yang menyelenggarakan pelayanan kesehatan secara paripurna yang memiliki risiko tinggi terhadap keselamatan pasien, pendamping pasien, pengunjung, maupun sumber daya manusia dan lingkungan rumah sakit, sehingga perlu diselenggarakan keselamatan dan kesehatan agar tercipta kondisi rumah sakit yang sehat, aman, selamat dan nyaman secara berkesinambungan (KEMENKES RI, 2016). Penerapan keselamatan pasien dapat diwujudkan dengan menetapkan standar, sasaran dan langkah menuju keselamatan pasien dengan tujuan akhir yaitu memberikan asuhan pasien yang lebih aman (KEMENKES RI, 2017a).

Sebagai bagian terpadu dari sistem perawatan kesehatan yang luas, rumah sakit memiliki fokus dominan pada penyediaan layanan kesehatan untuk memenuhi, memelihara dan mempromosikan kebutuhan kesehatan masyarakat guna memenuhi kepuasan pasien (Shafii, Rafiei, Abooee, \& Amin, 2016). Bentuk usaha yang dilakukan untuk memenuhi kebutuhan pelayanan di rumah sakit dipengaruhi oleh kepuasan pasien yang dapat diukur melalui kehandalan, daya tanggap, empati, jaminan dan loyalitas pasien terhadap rumah sakit (Meesala \& Paul, 2016:Kitapci, Akdogan, \& Taylan, 2014) serta dukungan sarana dan prasarana yang memadai dalam menjamin kualitas pelayanan (Adzrieman, Rahman, Mohamad, Ashikin, \& Rahman, 2014).

Peningkatan kualitas pelayanan dalam upaya penyediaan layanan publik menjadi perhatian utama pemerintah terutama pelayanan kesehatan yang optimal guna memastikan kondisi kehidupan yang layak bagi seluruh masyarakat. Hal tersebut akan tercapai dengan melibatkan para pemangku kepentingan dan kerjasama antara akademisi, rumah sakit pemerintah dan perusahaan publik, sehingga pelayanan kesehatan dapat diberikan dan dirasakan oleh seluruh masyarakat indonesia (Fitriati \& Rahmayanti, 2012).

Usaha mewujudkan pelayanan kesehatan kesehatan yang bermutu,. (Mitropoulos, Vasileiou, \& Mitropoulos, 2017). Oleh sebab itu mengukur kualitas layanan merupakan prasyarat dasar untuk meningkatkan kualitas pelayanan rumah sakit (Mohebifar, Hasani, Barikani, \& Rafiei, 2016) untuk memenuhi, memelihara dan mempromosikan kebutuhan kesehatan masyarakat guna memenuhi kepuasan pasien (Shafii et al., 2016).

Pengukuran kualitas pelayanan merupakan salah satu tantangan yang harus dihadapi oleh setiap rumah sakit, sehingga hasilnya akan lebih ilmiah dan personal dalam menentukan kualitas pelayanan kinerja rumah sakit (Akdag, Kalaycı, Karagöz, Zülfikar, \& Giz, 2014). Indikator kinerja 
pelayanan Rumah Sakit berdasarkan Undang undang Republik Indonesia Nomor 44 tahun tahun 2009 tentang Rumah Sakit bahwa pelayanan kesehatan merupakan hak setiap orang yang dijamin oleh negara yang harus diwujudkan dengan upaya peningkatan derajat kesehatan masyarakat setinggi-tingginya (RI, 2012). Penerapan asuhan yang aman perlu dukungan, pembinaan dan pengawasan melalui sistem berjenjang yang bertujuan untuk memastikan pelaksanaan dan melaporkan perkembangan standar yang telah ditetapkan dan dipelaksanaankan guna menjamin pelayanan yang bermutu (KEMENKES RI, 2010).

Upaya meningkatkan kualitas sistem manajemen mutu di rumah sakit memerlukan komisi yang dapat mengendalikan mutu yang berdampak terhadap pengakuan publik (Jaiswal, 2016). Standar pelayanan rumah sakit bertujuan agar masyarakat mendapatkan mutu pelayanan yang baik karena sesuai dengan pasal 40 undang-undang Republik Indonesia bahwa dalam upaya peningkatan mutu pelayanan rumah sakit wajib dilakukan akreditasi secara berkala minimal tiga tahun sekali (KEMENKES $\mathrm{RI}, 2012$ ) yang berguna untuk memenuhi semua standar yang telah ditetapkan rumah sakit (Devkaran \& Farrell, 2015).

Akreditasi adalah pengakuan terhadap mutu palayanan rumah sakit setelah dilakukan penilaian oleh badan independen baik dari dalam maupun luar negeri berdasarkan standar akreditasi yang berlaku yang ditetapkan oleh menteri. Lembaga independen yang dapat melakukan akreditasi antara lain adalah Badan akreditasi internasional yaitu Joint Commision Internasinal $(\mathrm{JCl})$ dan komite akreditasi rumah sakit (KARS) (Permenkes 34, 2017).

Rumah sakit yang diakreditasi oleh Komisi Bersama cenderung memiliki kinerja dasar yang lebih baik daripada rumah sakit yang tidak terakreditasi. Rumah sakit terakreditasi memiliki keuntungan lebih besar dari waktu ke waktu, dan secara signifikan lebih cenderung memiliki kinerja tinggi.(Schmaltz, Williams, Chassin, \& Loeb, 2013). Dimensi utama yang perlu dipelaksanaankan oleh rumah sakit untuk memenuhi standar tersebut antara lain responsiveness, assurance, security, tangibles, komunikasi kesehatan, orientasi pasien.(Shafii et al., 2016) reliability, cost dan empathy yang diukur sesuai dengan standar yang berlaku (Untachai, 2013).

Pengukuran standar yang berlaku dalam akreditasi Rumah Sakit yang dilakukan Komisi Akreditasi Rumah Sakit terdiri dari empat kelompok yaitu standar pelayanan berfokus pada pasien, standar manajemen rumah sakit, sasaran keselamatan pasien serta kelompok sasaran milenium development goals dan dibagi kedalam 15 BAB atau standar yang harus dipenuhi sesuai dengan pelayanan yang diberikan (KEMENKES RI, 2017a).

Tuntutan dalam memenuhi semua standar pelayanan kesehatan termasuk pelayanan keperawatan yang profesional dengan standar internasional sudah didepan mata tidak lagi hanya berfokus pada kepuasan pasien tetapi lebih penting lagi adalah keselamatan pasien (patient safety). Harapan pelayanan profesional yang bermutu tinggi yang berfokus pada keselamatan (safety) dan kepuasan pasien dapat terlaksana (Setyarini EA, 2013) Oleh karena itu, keselamatan pasien merupakan prioritas utama untuk dilaksanakan di rumah sakit dan hal itu terkait dengan isu mutu dan citra rumah sakit. Oleh harena itu pelaksanaan sistem manajemen mutu dengan meningkatkan keselamatan pasien "patient safety" (Jaiswal, 2016), yang diharapkan dapat menurunkan angka kematian akibat cedera medis dapat dicegah dengan membangun dan membudayakan keselamatan pasien di rumah sakit (Bea, Pasinringi, \& Noo, 2013). Berdasarkan hal tersebut perlu monitoring dan evaluasi oleh tim KPRS (Keselamatan Pasien Rumah Sakit) secara periodik untuk meningkatkan kepatuhan pelaksanaan SPO Identifikasi Pasien dalam membangun dan membudayakan keselamatan pasien (Tulus $\mathrm{H}$ et al., 2015).

Evaluasi program peningkatan pelaksanaan keselamatan pasien dengan tujuan peningkatan kinerja untuk memperbaiki proses yang telah ada, memonitor dan mengevaluasi kinerja melalui pengumpulan data, menganalisis insiden dalam melakukan perubahan untuk meningkatkan kinerja standar keselamatan pasien pada rumah sakit yang akan diakreditasi maupun yang telah diakreditasi. Kualitas layanan rumah sakit terakreditasi lebih baik dari pada rumah sakit yang tidak atau belum terakreditasi terutama dalam pelaksanaan keselamatan pasien (Chang, 2014).

Proses pelaksanaan standar keselamatan pasien yang pertama kali dilakukan adalah dengan menerapkan ketepatan identifikasi pasein dengan minimal dua identitas yaitu nama lengkap dan tanggal lahir atau nomor rekam medik pada gelang identitas dengan bar-code (KEMENKES RI, 2017a). Hal tersebut harus dilakukan oleh setiap perawat dengan target capaian $100 \%$, karena bila terjadi kesalahan identifikasi pasien dapat mejadi akar penyebab banyak kesalahan. Lembaga nasional keselamatan pasien di Inggris melaporkan 236 kejadian near miss berhubungan dengan kehilangan gelang identitas selama november 2013 sampai juli 2015 (Setiyani, 2016).

Pencapaian standar keselamatan yang merupakan salah satu isu penting dalam 
penyelenggaraan pelayanan kesehatan di Rumah Sakit didukung dengan komunikasi yang berpengaruh sebesar 19\% (Lewis, Packard, \& Lewis, 2012) baik dengan menggunakan teknik SBAR (situation, background, assessment, recommendation) dan TBK (Tulis, Baca, Konfirmasi) yang membutuhkan sarana prasarana yaitu lembar konfirmasi (Ulva, 2017). Hal tersebut terjadi karena belum optimalnya pelaksanaan sistem supervisi terhadap pelaksanaan prosedur identifikasi yang belum optimal serta budaya safety yang masih perlu terus ditingkatkan (Anggraeni, Hakim, \& I, 2014).

Data yang didapatkan dari TIM PPI RSU kabupaten tangerang pada bulan agustus 2016 bahwa jumlah insiden keslematan pasien berjumlah 31 kasus (Setiyani, 2016). Penyelenggaraan keselamatan pasien yang berkesinambungan dilakukan dengan pembentukan sistem yang terdiri dari standar, sasaran dan langkah - langkah, (KEMENKES RI, 2017a). Penerapan keselamatan pasien secara berkesinambungan dapat dilakukan dengan supervisi buna meningkatkan penerapan budaya keselamatan pasien oleh perawat pelaksana (Saraswati, 2014).

Penelitian lain tentang faktor yang berhubungan dengan kinerja perawat dalam pelaksanaan sasaran keselamatan pasien di Rumah Sakit Stella Maris Makasar dengan hasil penelitian bahwa sumber daya, kepemimpinan, imbalan dan struktur organisasi yang baik berdampak pada penerapan keselamatan pasien di rumah sakit (Jumriani, Noor, \& Rivai, 2016). Keselamatan pasien juga didukung oleh faktor pendidikan, lama kerja (Setyarini EA, 2013) karena semakin lama masa kerja maka semakin baik upaya mengpelaksanaankan standar keselamatan pasien (Satria, Sidin, \& Noor, 2013b). Selain itu pelatihan patient safety juga berhubungan dengan pelaksanaan sasaran keselamatan pasein (Yulia. S \& Hamid AY, 2012) Tersedianya sarana, dan SOP dapat berpengaruh terhadap upaya pencegahan insiden infeksi nosokomial yang berdampak pada keselamatan pasien (Lindawati, 2013).

Identifikasi pasien, pelaksanaan komunikasi efektif, pelaksanaan peningkatan keamanan obat yang perlu diwaspadai, pelaksanaan kepastian tepat-lokasi, tepat - prosedur, tepat pasien operasi sudah sesuai dengan standar akreditasi rumah sakit versi 2012 sedangkan pelaksanaan pengurangan risiko infeksi dan pelaksanaan pengurangan risiko pasien jatuh belum sesuai dengan standar akreditasi rumah sakit (Keles \& Ch, 2012). Evaluasi pelaksanaan sasaran keselamatan pasien menggunakan KARS 2012 di RSIA PKU Muhammadiyah Kotagede Yogyakarta belum sepenuhnya dipelaksanaankan terkait kebijakan yang belum sepenuhnya dibuat dan silaksanakan serta kurangnya sosialisasi, motivasi, pengawasan dan dukungan dari manajemen rumah sakit (Sundoro, Rosa, \& Risdiana, 2016). Penelitian yang dilakukan Hardiatma $R$, dkk pada tahun 2015 tentang pelaksanaan sasaran keselamatan pasien dalam upaya menghadapi akreditasi klinik bab 4 mendapatkan nilai peningkatan dokumen $90 \%$, perilaku $80 \%$ dan akreditasi mendapat capaian nilai $89,66 \%$. Hambatan yang dihadapi adalah kurangnya pelaksanaan terkait pengawasan dalam pelaporan insiden keselamatan pasien (Kejadian Tidak Diharapkan, Kondisi Potensial Cidera, Kondisi Nyaris Cidera) (Rio Hardiatma, Arlina Dewi, 2015). Hal tersebut berdampak pada evaluasi akreditasi rumah sakit sebelumnya yang sering mengalami hambatan. Salah satu cara untuk menilai dampak ini adalah membandingkan status akreditasi dengan ukuran kualitas berbasis bukti lainnya, seperti langkah-langkah proses yang sekarang dilaporkan dengan pelaksanaan secara berkesinambungan (Schmaltz et al., 2013), serta pengawasan terhadap budaya safety yang masih perlu terus ditingkatkan (Anggraeni et al., 2014).

Berdasarkan data yang didapatkan dari KARS tahun 2017 bahwa jumlah Rumah sakit di Kota Palembang yang telah lulus akreditasi versi 2012 sebanyak 18 Rumah Sakit pemerintah dan swasta dengan berbagai status akreditasi. Diantaranya11 Rumah Sakit dengan status akreditasi Paripurna, 2 Rumah Sakit dengan status akreditasi tingkat utama, 6 rumah sakit dengan status akreditasi lulus perdana (KARS, 2012)

Rumah Sakit "X" merupakan Rumah Sakit Swasta tipe C yang memiliki 7 Ruang Rawat Inap dengan kapasitas 221 tempat tidur yang menjadi rujukan kesehatan di Kota Palembang dan Propinsi Sumatera Selatan serta telah mendapatkan Status Akreditasi Paripurna pada 5 September 2017 dan berlaku sampai dengan 5 september 2020. Data insiden keselamatan pasien pada tahun 2015 tercatat terjadi plebitis $0,8 \%$ dari seluruh pasien dirawat inap, tahun 2016 kejadian plebitis masih terjadi 0,08\% sedangkan pada tahun 2017 kejadian plebitis terjadi $0,2 \%$ dan Infeksi Daerah Operasi (IDO) sebesar 0,5\%. Data kepatuhan pelaksanaan hand hygiene tercatat pada tahun 2015 (58\%), tahun 2016, (62\%) dan tahun 2017 (72\%), sedangkan insiden yang terdiri dari Kejadian tidak diharapkan (KTD) (4\%), Kejadian Nyaris Cedera (KNC) (1\%), serta kejadian tidak cedera (KTC) (2\%) (RSMP, 2017).

Hasil observasi dan wawancara terhadap 10 pasien dan perawat di ruangan pada saat peneliti melaksanakan kegiatan residensi pada bulan September sampai dengan Desember 2017 didapatkan hasil bahwa beberapa pasien 
mengeluh jika setiap akan dilakukan tindakan ditanyakan identitasnya, lamanya respon perawat saat pasien memerlukan bantuan serta kesulitan mendapatkan informasi tentang kondisi pasien berupa hasil pemeriksaan dan tindakan yang akan dilakukan serta perbedaan penjelasan tentang kondisi pasien oleh setiap petugas. Selain itu hasil wawancara dan observasi pada beberapa perawat yang mengeluhkan catatan oleh rekan medis lain pada lembar catatan perkembangan pasien terintegrasi (CPPT) dengan tulisan yang sulit untuk dibaca yang mengakibatkan harus mengkoorfirmasi dengan yang orang bersangkutan dalam menentukan rencana dan pelaksanaan tindakan kepada pasien.

Selain itu, jika terjadi kesalahan pada saat pemberian tindakan yang hanya diketahui oleh perawat, mereka enggan mengklarifikasi dan berkonsultasi dengan perawat senior, penanggung jawab tim dan kepala ruangan karena akan memperpanjang dan menimbulkan masalah baru yang semestinya kejadian tersebut diselesaikan sehingga tidak berdampak negatif pada perawat dan pasien.

Hal lain yaitu masih minimnya petunjuk pelaksanaan pencampuran obat terutama obat obatan high alert. Permasalahan pada penyediaan fasilitas antara lain fasilitas cuci tangan yang kadang tidak terisi sedangkan petunjuk dan sosialisai hand hygiene dilakukan terjadwal oleh tim pencegahan dan pengendalian infeksi (PPI), pengering tangan tidak tersedia, penggunaan gelang yang belum seragam terutama penyediaan alat barcode yang memudahkan perawat dan tim medis lainnya dalam melakukan identifikasi pada pasien, penyediaan tempat tidur pasien masih menggunakan tempat tidur lama yang kurang ergonomis terutama untuk pasien-pasien dengan resiko jatuh. selain itu informasi yang didapatkan dengan wawancara kepada enam kepala ruangan yang mengatkan bahwa pelaksanaan pengawasan sangat penting karena dengan adanya pengawasan akan dapat diketahui kinerja pelaksanaan pelayanan keperawatan terutama dalam pelaksanaan keselamatan pasien.

Pelaksanaan keselamatan pasien di Rumah Sakit "X" telah di pelaksanaankan dan dikordinir oleh komite mutu dan kelompok kerja (POKJA) sasaran keselamatan pasien (SKP). Hasil wawancara didapatkan informasi bahwa, hasil akreditasi pada POKJA SKP masih terdapat beberapa rekomendasi dari Surveyor Akreditasi Komite Akreditasi Rumah SAkit (KARS) yang perlu diperbaiki terkait keselamatan pasien, antara lain; pada sasaran (III= keamanan obat) merevisi panduan dan standar opersional prosedur (SPO), menetapkan kompetensi perawat dalam pemberian obat high alert, melakukan In House Training tentang pemberian obat yang perlu di waspadai, dan menyusun daftar cairan elektrolit koncentrate setiap unit pelayanan pasien. Pada sasaran (IV= tepat lokasi, tepat prosedur, dan tepat pasien operasi) dengan melengkapi kebijakan dan prosedur untuk memastikan tepat lokasi, tepat prosedur, dan tepat pasien termasuk dengan prosedur tindakan pengobatan gigi/dental yang dilaksanakan diluar kamar operasi dan melaksanakan monitoring. Pada sasaran ( $\mathrm{V}=$ mengurangi risiko infeksi yang terkait pelayanan kesehatan) dengan membuat laporan lengkap hand hygiene sesuai dengan program. Pada sasaran (VI; melakukan asesmen ulang terhadap pasien yang mengalami perubahan kondisi secara optimal, setiap pasien yang berisiko jatuh, lakukan langkah-langkah mengurangi risiko pasien jatuh, memfasilitasi pelaksanaan dengan form dan langkahlangkahnya setiap pasien yang berisiko jatuh, melakukan monitoring keberhasilan pengurangan cidera akibat jatuh, serta edukasi pasien tentang pasien jatuh.

Upaya yang perlu dilakukan dalam usaha memperbaiki dan meningkatkan menjamin keselamatan pasien dapat dilakukan dengan melakukan kegiatan supervisi oleh pihak manajemen rumah sakit terhadap pelaksanaan kerja perawat pelaksana dalam memberikan asuhan keperawatan. Hal tersebut perlu di eksplorasi dengan melakukan penelitian tentang hubungan karakteristik perawat terhadap pelaksanaansasaran keselamatan pasien oleh perawat pasca akreditasi Rumah Sakit "X" di kota Palembang.

\section{METODE PENELITIAN}

Penelitian ini merupakan penelitian kuantitatif dengan menggunakan metode deskriptif analitik melalui pendekatan Cross Sectional yang semua variabelnya diteliti dalam waktu yang bersamaan.. Populasi dalam penelitian ini adalah seluruh perawat pelaksana di ruang rawat inap Rumah sakit " $X$ " kota Palembang dengan jumlah sampel sebanyak 96 responden. Penelitian ini dilakukan pada 27 maret 2018 sampai dengan 21 april 2018 dengan menggunakan kuisioner dan dianalisis menggunakan sistem komputer

\section{HASIL DAN PEMBAHASAN}

Hasil Penelitian meliputi karakteristik perawat, pelaksanaan sasaran keselamatan pasien dan hubungan karakteristik dengan pelaksanan sasaran keselamatan pasien. 
Tabel 1

Distribusi frekuensi karakteristik perawat $(\mathrm{n}=96)$

\begin{tabular}{ccc}
\multicolumn{3}{c}{ Distribusi frekuensi karakteristik perawat $(\mathbf{n}=96)$} \\
\hline Variabel & Jumlah sampel & $\%$ \\
\hline Pendidikan & & \\
Vokasi (DIII \& S1) & 94 & 97,9 \\
Profesi (Ners) & 2 & 2,1
\end{tabular}

$\begin{array}{ccc}\begin{array}{l}\text { Jenis Kelamin } \\ \text { Perempuan }\end{array} & & \\ \text { Laki-Laki } & 11 & 88,5 \\ \text { Masa Kerja } & & 11,5 \\ \leq 2 \text { tahun } & 6 & \\ >2 \text { tahun } & 90 & 6,2 \\ \end{array}$

Tabel 2

Distribusi frekuensi variabel usia $(n=96)$

\begin{tabular}{ccccc}
\hline Variabel & Mean & Std. Deviasi & Minimal - maksimal & 95\% Cl \\
\hline Usia & 31,47 & 4,27 & $22-43$ & $30,61-32,34$ \\
\hline
\end{tabular}

Berdasarkan analisis hasil penelitian pada tabel 1 menunjukkan bahwa dari 96 perawat di Rumah Sakit "X"Palembang sebagian besar berpendidikan vokasi $(97,9 \%)$, sebagaian besar berjenis kelamin perempuan $(88,5 \%)$, sebagian besar berusia $<35$ tahun $(52,1)$, sebagaian besar masa kerja $>2$ tahun $(93,8 \%)$. Sedangkan hasil analisis pada tabel 2 didapatkan rata-rata usia responden adalah 31,47 tahun (95\% Cl: 30,61 - 32,34), dengan standar deviasi 4,27 tahun. Umur termuda 22 tahun dan umur tertua 43 tahun. Dari hasil estimasi interval dapat disimpulkan bahwa 95\% diyakini bahwa rata-rata usia responden adalah diantara 22 tahun sampai dengan 43 tahun
Tabel 3

Distribusi frekuensi pelaksanaan sasaran keselamatan

\begin{tabular}{llcc}
\multicolumn{3}{c}{ pasien } \\
\hline & $\begin{array}{l}\text { Pelaksanaan Sasaran } \\
\text { Keselamatan Pasien }\end{array}$ & $\begin{array}{l}\text { Jumlah } \\
\text { sampel }\end{array}$ & $\%$ \\
\hline a. & Kurang Baik & 15 & 15,6 \\
\hline b. & Baik & 81 & 84,4 \\
\hline
\end{tabular}

Berdasarkan analisis hasil penelitian pada tabel 3 terkait pelaksanaan sasaran keselamatan pasien oleh perawat menunjukkan bahwa dari 96 perawat, 81 perawat $(84,4 \%)$ dengan kategori pelaksanaan sasaran keselamatan pasien baik dan 15 perawat $(15,6 \%)$ dengan kategori pelaksanaan sasaran keselamatan pasien kurang baik.

Diagram 1

Distribusi frekuensi Pelaksanaan Sasaran Keselamatan Pasien

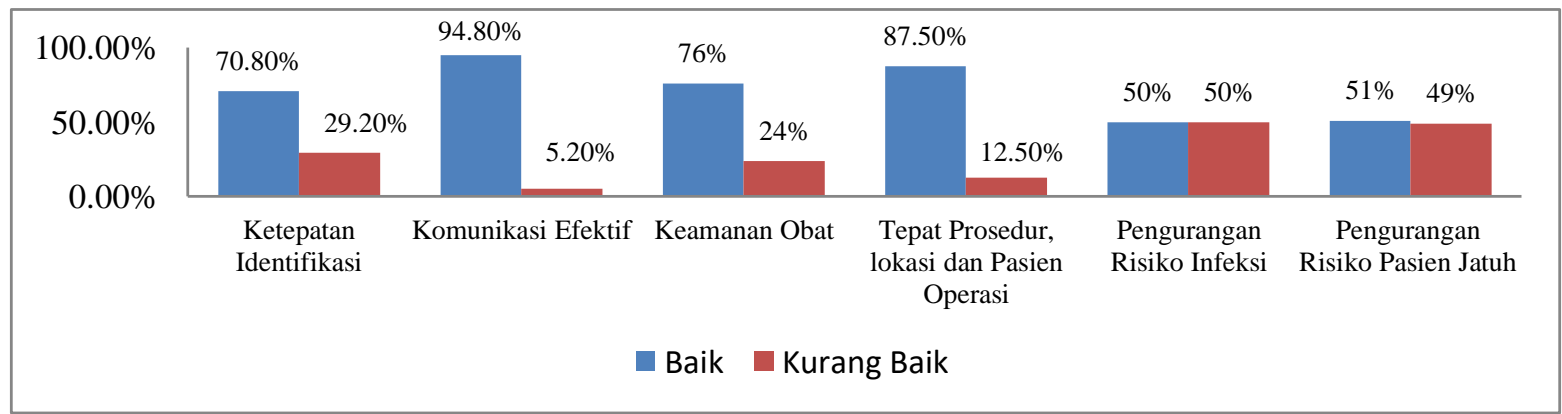

Berdasarkan hasil analisis pada diagram 1 diatas diketahui hasil analisis distribusi frekuensi pelaksanaan enam sasaran standar keselamatan pasien dari 96 perawat diketahui bahwa; pelaksanaan sasaran identifikasi baik 68 $(70,8 \%)$ kurang baik $28(29,2 \%)$. Pelaksanaan pada sasaran komunikasi baik 91 (94,8\%) dan pelaksanaan sasaran komunikasi kurang baik 5 $(5,2 \%)$. Pelaksanaan pada sasaran keamanan obat baik $73(76,0 \%)$ dan pelaksanaan sasaran keamanan obat kurang baik 23 (24,0\%).
Pelaksanaan pada sasaran tepat prosedur, lokasi dan pasien operasi baik $84(87,5 \%)$ dan pelaksanaan sasaran tepat prosedur,lokasi dan pasien operasi kurang baik 12 (12,5\%). Pelaksanaan pada sasaran pengurangan risiko infeksi baik $48(50 \%)$ dan pelaksanaan sasaran pengurangan risiko infeksi kurang baik 48 $(50,0 \%)$. Pelaksanaan pada sasaran pengurangan risiko pasien jatuh baik $49(51,0 \%)$ dan pelaksanaan sasaran pengurangan risiko pasien jatuh kurang baik 47 (49,0\%).

Tabel 4

Hubungan pendidikan dengan pelaksanaan sasaran keselamatan pasien

\begin{tabular}{|c|c|c|c|c|c|c|c|c|c|}
\hline \multirow{3}{*}{ Variabel } & \multirow{3}{*}{ Kriteria } & \multicolumn{4}{|c|}{$\begin{array}{c}\text { Pelaksanaan sasaran keselamatan } \\
\text { pasien }\end{array}$} & & & \multirow{3}{*}{$\begin{array}{c}p \\
\text { Value }\end{array}$} & \multirow{3}{*}{$\begin{array}{c}\text { OR } \\
\text { (CI95\%) }\end{array}$} \\
\hline & & \multicolumn{2}{|c|}{ Baik } & \multicolumn{2}{|c|}{ Kurang Baik } & \multicolumn{2}{|c|}{ Jumlah } & & \\
\hline & & $n$ & $\%$ & $n$ & $\%$ & $N$ & $\%$ & & \\
\hline \multirow[b]{2}{*}{ Pendidikan } & Vokasi & 79 & 84,0 & 15 & 16,0 & 94 & 100 & \multirow[b]{2}{*}{1,000} & \multirow[b]{2}{*}{$\begin{array}{c}0,840(0,770- \\
0,918)\end{array}$} \\
\hline & Profesi & $\begin{array}{c}2 \\
81\end{array}$ & $\begin{array}{r}100 \\
84,0\end{array}$ & $\begin{array}{c}0 \\
15\end{array}$ & $\begin{array}{c}0 \\
16,0\end{array}$ & $\begin{array}{c}2 \\
96\end{array}$ & $\begin{array}{l}100 \\
100\end{array}$ & & \\
\hline
\end{tabular}


Berdasarkan table 4, perawat dengan pendidikan vokasi dan baik dalam pelaksanaan sasaran keselamatan pasien $79(84,05)$ dari 94 perawat, lebih besar disbanding dengan perawat dengan pendidikan profesi dan baik dalam pelaksanaan sasaran keselamatan pasien 2 $(100 \%)$ dari 2 perawat. Hasil uji statistiik dengan menggunakan chi square didapatkan $p$-value $=$ 1,000 lebih besar dari $\alpha=0,05$ yang berarti ho $=$ diterima sehingga dinyatakan tidak ada hubungan yang bermakna antara pendidikan dengan pelaksanaan sasaran keselamatan pasien oleh perawat pasca akreditasi Rumah Sakit "X"Palembang tahun 2018. Hasil analisis diperoleh pula nilai $\mathrm{OR}=0,840$ artinya perawat yang berpendidikan Profesi mempunyai peluang 0,840 kali untuk kurang baik dalam pelaksanaan sasaran keselamatan pasien dibandingkan dengan perawat berpendidikan vokasi.

Tabel 5

Hubungan jenis kelamin dengan pelaksanaan sasaran keselamatan pasien

\begin{tabular}{|c|c|c|c|c|c|c|c|c|c|}
\hline \multirow{3}{*}{ Variabel } & \multirow{3}{*}{ Kriteria } & \multicolumn{4}{|c|}{$\begin{array}{c}\text { Pelaksanaan sasaran keselamatar } \\
\text { pasien }\end{array}$} & & & \multirow{3}{*}{$\begin{array}{c}p \\
\text { Value }\end{array}$} & \multirow{3}{*}{$\begin{array}{c}\text { OR } \\
\text { (Cl95\%) }\end{array}$} \\
\hline & & \multicolumn{2}{|c|}{ Baik } & \multicolumn{2}{|c|}{ Kurang Baik } & \multicolumn{2}{|c|}{ Jumlah } & & \\
\hline & & $n$ & $\%$ & $n$ & $\%$ & $n$ & $\%$ & & \\
\hline \multirow[b]{2}{*}{ Jenis Kelamin } & Perempuan & 72 & 84,7 & 13 & 15,3 & 85 & 100 & \multirow[b]{2}{*}{0,681} & \multirow[b]{2}{*}{$\begin{array}{c}0,812 \\
(0,157-4,197)\end{array}$} \\
\hline & Laki-laki & $\begin{array}{c}9 \\
81\end{array}$ & $\begin{array}{l}81,8 \\
84,0\end{array}$ & $\begin{array}{c}2 \\
15\end{array}$ & $\begin{array}{l}18,2 \\
16,0\end{array}$ & $\begin{array}{l}11 \\
96\end{array}$ & $\begin{array}{l}100 \\
100\end{array}$ & & \\
\hline
\end{tabular}

Berdasarkan table 5, perawat dengan jenis kelamin perempuan dan baik dalam pelaksanaan sasaran keselamatan pasien 72 $(84,7 \%)$ dari 85 perawat, lebih besar dibanding dengan perawat dengan jenis kelamin laki-laki dan baik dalam pelaksanaan sasaran keselamatan pasien $9(81,8 \% \%)$ dari 11 perawat. Hasil uji statistiik dengan menggunakan chi square didapatkan $p$-value $=0,681$ lebih besar dari $\alpha=0,05$ yang berarti ho = diterima sehingga dinyatakan tidak ada hubungan yang bermakna antara jenis kelamin dengan pelaksanaan sasaran keselamatan pasien oleh perawat pasca akreditasi Rumah Sakit "X"Palembang tahun 2018. Hasil analisis diperoleh pula nilai $\mathrm{OR}=0,812$ artinya perawat yang berjenis kelamin laki-laki mempunyai peluang 0,812 kali untuk kurang baik dalam pelaksanaan sasaran keselamatan pasien dibandingkan dengan perawat berjenis kelamin perempuan.

Tabel 6

Hubungan masa kerja dengan implementasi sasaran keselamatan pasien

\begin{tabular}{|c|c|c|c|c|c|c|c|c|c|}
\hline \multirow{3}{*}{ Variabel } & \multirow{3}{*}{ Kriteria } & \multicolumn{4}{|c|}{$\begin{array}{l}\text { Implementasi sasaran } \\
\text { keselamatan pasien }\end{array}$} & \multirow{2}{*}{\multicolumn{2}{|c|}{ Jumlah }} & \multirow{3}{*}{$\begin{array}{c}p \\
\text { Value }\end{array}$} & \multirow{3}{*}{$\begin{array}{c}\text { OR } \\
\text { (Cl95\%) }\end{array}$} \\
\hline & & \multicolumn{2}{|c|}{ Baik } & \multicolumn{2}{|c|}{ Kurang Baik } & & & & \\
\hline & & $N$ & $\%$ & $n$ & $\%$ & $n$ & $\%$ & & \\
\hline \multirow[b]{2}{*}{ Masa Kerja } & $>2$ tahun & 75 & 83,3 & 15 & 16,7 & 90 & 100 & \multirow[b]{2}{*}{0,585} & \multirow{2}{*}{$\begin{array}{c}1,200 \\
(1,094-1,316)\end{array}$} \\
\hline & $\leq 2$ tahun & $\begin{array}{c}6 \\
81\end{array}$ & $\begin{array}{r}100 \\
\mathbf{8 4 , 0}\end{array}$ & $\begin{array}{c}0 \\
15\end{array}$ & $\begin{array}{c}0 \\
16,0\end{array}$ & $\begin{array}{c}6 \\
96\end{array}$ & $\begin{array}{l}100 \\
100\end{array}$ & & \\
\hline
\end{tabular}

Berdasarkan table 6 , perawat dengan masa kerja > 2 tahun dan baik dalam implementasi sasaran keselamatan pasien 75 $(83,3 \%)$ dari 90 perawat, lebih besar dibanding dengan perawat dengan masa kerja $\leq 2$ tahun dan baik dalam implementasi sasaran keselamatan pasien $6(100 \% \%)$ dari 6 perawat. Hasil uji statistiik dengan menggunakan chi square didapatkan $p$-value $=0,585$ lebih besar dari $\alpha=0,05$ yang berarti ho $=$ diterima sehingga dinyatakan tidak ada hubungan yang bermakna antara masa kerja dengan implementasi sasaran keselamatan pasien oleh perawat pasca akreditasi Rumah Sakit "X"Palembang tahun 2018. Sedangkan dari hasil analisis diperoleh pula nilai $\mathrm{OR}=1,200$ artinya perawat dengan masa kerja $>2$ tahun mempunyai peluang 1,200 kali untuk kurang baik dalam implementasi sasaran keselamatan pasien dibandingkan perawat dengan masa kerja $\leq 2$ tahun.

Tabel 7

Hubungan usia dengan implementasi sasaran keselamatan pasien

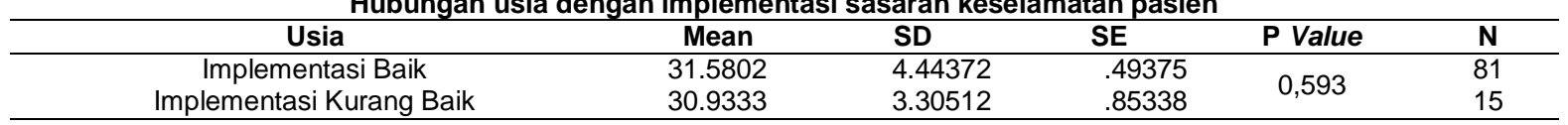

Berdasarkan tabel 7 menunjukkan bahwa rata - rata usia perawat dengan implementasi sasaran keselamatan pasien baik adalah 31,5 tahun dengan standar deviasi 4,44. Sedangkan untuk usia perawat dengan implementasi sasaran keselamatan pasien kurang baik adalah 30,9 tahun dengan standar deviasi 3,30. Hasil uji statistik didapatkan nilai $p$ value $=0,593$, berarti 
pada alpha $5 \%$ terlihat tidak ada perbedaan yang signifikan rata - rata usia perawat yang mengimplementasikan sasaran keselamatan pasien secara baik dengan perawat yang mengimplementasikan sasaran keselamatan pasien kurang baik di Rumah Sakit "X"Palembang tahun 2018.

\section{HASIL DAN PEMBAHASAN Pendidikan}

Berdasarkan hasil penelitian diketahui bahwa pendidikan perawat pada tahap Vokasi 94 orang $(97,9 \%)$ dengan implementasi standar keselamatan baik (84\%) yang menunjukkan bahwa sebagian besar perawat dengan tahap pendidikan vokasi telah mengimplementasi sasaran keselamatan dengan baik. Karena tingkat pendidikan merupakan salah satu karakteristik individu yang dapat meningkatkan pengetahuan perawat untuk dapat menerapkan patient safety (Yulia, Sri, 2012). Sedangkan hasil analisa bivariat tidak terdapat hubungan antara pendidikan dengan Implementasi sasaran keselamatan pasien dengan $p$ value $(1,000)$ dan didapatkan nilai Odds Ratio (OR) $=0,918$, artinya pendidikan mempunyai peluang 0,9 lebih besar dibandingkan pendidikan profesional dalam implementasi standar keselamatan pasien dikarenakan perbedaan jumlah sumber daya manusia professional yang masih sangat minim.

Penelitian ini tidak sejalan dengan penelitian yang dilakukan (Meliana, Anggraeni, \& Maidin, 2013) bahwa pendidikan tidak berhubungan dengan kepatuhan perawat dalam menerapkan keselamatan pasien. Berbeda dengan hasil penelitian yang dilakukan (Setiyani, 2016) bahwa hubungan Pendidikan Terakhir dengan Implementasi Sasaran Keselamatan Pasien, diperoleh nilai pvalue $=0.043$ dimana nilai $p$-value < a 0.05, Maka terdapat hubungan antara Pendidikan Terakhir dengan Implementasi asaran Keselamatan Pasien. Dari hasil analisa diperoleh nilai $\mathrm{OR}=0.076$ artinya perawat yang memiliki pendidikan terakhir S1 Keperawatan memiliki peluang 0.076 kali untuk mengimplementasikan Sasaran Keselamatan Pasien dengan Baik dibandingkan dengan perawat yang memiliki pendidikan DIII Keperawatan. Hasil penelitian ini tidak sejalan dengan penelitian yang dilakukan oleh (Khaerunnisa Apriani, 2016). Namun menurut (Sabila Diena Rosyada, 2014), kemahiran bekerja tergantung pada tingkat pendidikan, pengetahuan, dan pengalaman seseorang.

Pendidikan merupakan sebuah proses pengubahan sikap dan tingkah laku melalui pengajaran dan pelatihan formal maupun non formal yang pada akhirnya akan menghasilkan pengetahuan (Notoatmodjo, 2010). Perlu adanya jenis tenaga perawat berpendidikan lebih tinggi untuk meningkatkan mutu pelayanan
Keperawatan (WHO, 2015). Penelitian yang dilakukan (Setyarini, EA, 2014) dan (Astriana. N \& Sidin, 2014) bahwa pendidikan berhubungan dengan kepatuhan perawat melaksanakan keselamatan pasien.

Berdasarkan hasil penelitian dan teori diatas dapat disimpulkan bahwa pihak manajemen rumah sakit perlu melakukan mapping dan upaya peingkatan kualifikasi sumber daya manusia (perawat), selain sebagai upaya meningkatkan pemahaman secara kontekstual, juga diharapkan dapat meningkatkan kinerja yang lebih optimal terutama dalam implementasi sasaran keselamatan pasien. Hal tersebut juga mendukung upaya yang dilakukan oleh pemerintah tentang penentuan jenjang karis perawat yang telah diatur dalam Peraaturan Menteri Kesehatan $\mathrm{Ri}$ no.40 Tentang Pengembangan jenjang karir perawat (KEMENKES RI, 2017c)

\section{Jenis Kelamin}

Berdasarkan hasil penelitian diketahui bahwa jenis kelamin didominasi oleh perawat perempuan $(88,5 \%)$ dengan implementasi sasaran keselamatan baik (84\%) yang menunjukkan bahwa sebagian besar perawat dengan jenis kelamin perempuan telah mengimplementasi standar keselamatan dengan baik. Sedangkan hasil analisa bivariat tidak terdapat hubungan antara jenis kelamin dengan Implementasi sasaran keselamatan pasien dengan $p$ value $(0,681)$.

Kemampuan mempelajari dan dalam bertindak tidak dipengaruhi oleh jenis kelamin, dimana jenis kelamin sebagian besar perawat adalah perempuan. Laki-laki dan perempuan adalah sama dalam hal kemampuan belajar dan bertindak, daya ingat, kemampuan penalaran, kreativitas, dan kecerdasan. Meskipun beberapa peneliti masih percaya adanya perbedaan kreativitas, penalaran, dan kemampuan antara pria dan wanita (WHO, 2015). Penelitian ini sejalan dengan penelitian yang dilakukan oleh (Setiyani, 2016) bahwa (93,5\%) perawat berjenis kelamin perempuan dan melaksanakan keselamatan pasien dengan baik. Walaupun penelitian ini tidak sejalan dengan penelitian yang dilakukan (Meliana et al., 2013) bahwa jenis kelamin tidak berhubungan dengan kepatuhan perawat dalam menerapkan keselamatan pasien

Berdasarkan hasil penelitian dan teori diatas dapat disimpulkan bahwa perawat dirumah sakit lebih didominasi oleh jenis kelamin perempuan. Hal tersebut tidak berati bahwa hanya perempuan yang mengimplementasikan sasaran keselamatan pasien karena keselamatan pasien merupakan tanggung jawab 
setiap perawat dan tim medis lain yang berada di rumah sakit (KEMENKES RI, 2017b).

\section{Masa Kerja}

Berdasarkan hasil penelitian diketahui bahwa sebagian besar perawat $(93,8 \%)$ dengan masa kerja lebih dari 2 tahun, sedangkan hasil analisa bivariat tidak terdapat hubungan antara masa kerja dengan Implementasi sasaran keselamatan pasien dengan $p$ value $(0,585)$. Hasil penelitian ini berbeda dengan hasil penelitian yang telah dilakukan oleh (Setiyani, 2016) diperoleh nilai $p$-value $=0.008$ dimana nilai $p$-value < a 0.05, maka terdapat hubungan antara Lama kerja perawat dengan Implementasi Sasaran Keselamatan Pasien dan dari dari hasil analisa diperoleh nilai $\mathrm{OR}=0.062$ artinya perawat yang lamabekerjanya tinggi ( $>5$ tahun) memiliki peluang 0.062 kali untuk mengimplementasikan Sasaran Keselamatan Pasien dengan Baik dibandingkan dengan perawat yang lama bekerjanya rendah $(=5$ tahun).

Penelitian ini sejalan dengan penelitian yang dilakukan (Satria, Sidin, \& Noor, 2013a) bahwa semakin lama masa kerja maka semakin baik upaya mengimplementasikan standar keselamatan pasien, karena Masa kerja adalah merupakan pengalaman individu yang akan menentukan pertumbuhan dalam pekerjaan dan jabatan (UU RI No 13, 2003). Hasil penelitian lain yang dilakukan (Harus, 2015), bahwa lama kerja berkaitan dengan pengalaman kerja, dimana merupakan salah satu faktor kunci dalam keselamatan pasien di rumah sakit. peneliti berasumsi bahwa masa kerja $>2$ tahun termasuk dalam kategori senior yang berarti bahwa perawat yang bekerja di rumah sakit memiliki masa kerja yang lama. Hal tersebut sangat mendukung perawat dalam implementasi sasaran keselamatan pasien, karena setiap perawat harus mengimplementasikan keselamatan pasien sejak dinyatakan menjadi bagian dari pelayanan keperawatandi rumah sakit.

\section{Usia}

Berdasarkan hasil penelitian diketahui bahwa sebagian perawat berusia <35 tahun $(51,1 \%)$ dengan implementasi sasaran keselamatan baik (82\%) yang menunjukkan bahwa sebagian besar perawat dengan usia < 35 tahun telah mengimplementasi sasaran keselamatan dengan baik. Sedangkan hasil analisa bivariat tidak terdapat hubungan antara usia perawat dengan Implementasi sasaran keselamatan pasien dengan $p$ value $(0,699)$.

Umur atau usia mempengaruhi daya tangkap dan pola pikir. Semakin tua semakin bijaksana dan tidak dapat mengajarkan kepandaian baru kepada orang yang sudah tua karena kemunduran fungsi fisik dan mental (WHO, 2015). Mayoritas perawat di Rumah Sakit berada di rentang usia 31 tahun, hal tersebut menunjukkan bahwa perawat berada pada rentang umur dewasa muda, dimana usia muda memiliki rasa igin tahu dan mudah beradaptasi (Bea et al., 2013). Penelitian ini sejalan dengan penelitian yang dilakukan (Meliana et al., 2013) bahwa usia berhubungan dengan kepatuhan perawat dalam menerapkan keselamatan pasien.

Berdasarkan hasil penelitian dan teori diatas dapat disimpulkan bahwa usia dapat menggambarkan perilaku perawat dalam kinerja terutama tanggung jawab dalam mengimplementasikan sasaran keselamatan pasien dengan baik. Usia perawat 31 tahun masih tergolong dalam kategori usia dewasa muda yang dianggap akan lebih mudah untuk menerima perubahan terutama dalam pelaksanaan keselamatan pasien.

\section{SIMPULAN}

Berdasarkan hasil penelitian dan uraian pembahasan dapat disimpulkan bahwa:

1. Sebagian besar responden berpendidikan Diploma III, sebagian besar berjenis kelamin perempuan, berusia $<35$ tahun dan dengan masa kerja $>2$ tahun

2. Sebagian besar perawat telah mengimplementasikan standar keselamatan pasien dengan baik

3. Tidak terdapat hubungan antara pendidikan, jenis kelamin, usia dan masa kerja dengan pelaksanaan sasaran keselamatan pasien oleh perawat pasca Akreditasi Rumah Sakit "X" di Kota Palembang

\section{DAFTAR PUSTAKA}

Adzrieman, N., Rahman, A., Mohamad, B., Ashikin, N., \& Rahman, A. (2014). Factors Influencing the Quality of e-Services on Hospital Information System ( HIS ) in Malaysia. Procedia - Social and Behavioral Sciences, 155(October), 507512.

https://doi.org/10.1016/j.sbspro.2014.10.3 31

Akdag, H., Kalaycı, T., Karagöz, S., Zülfikar, H., \& Giz, D. (2014). The evaluation of hospital service quality by fuzzy MCDM. Applied Soft Computing Journal, 23, 239248.

https://doi.org/10.1016/j.asoc.2014.06.033

Anggraeni, D., Hakim, L., \& I, C. W. (2014). Evaluasi Pelaksanaan Sistem Identifikasi Pasien di Instalasi Rawat Inap Rumah Sakit Evaluation on Patient Identification System Implementationin Hospital â€ $€^{\mathrm{TM}} \mathrm{s}$ Inpatient Unit, 28(1), 99-104.

Astriana. N, N. B., \& Sidin, A. I. (2014). Relation 
of Education, Years of Work and Workload on Patient Safety Of Haji Makassar Hospital, 1-8.

Bea, I. F., Pasinringi, S. A., \& Noo, N. B. (2013). Gambaran Budaya Keselamatan Pasien di Rumah Sakit Universitas Hasanudin Tahun 2013, 1-14.

Chang, T. (2014). Fuzzy VIKOR method: A case study of the hospital service evaluation in Taiwan. INFORMATION SCIENCES, (March). https://doi.org/10.1016/j.ins.2014.02.118

Devkaran, S., \& Farrell, P. N. O. (2015). The impact of hospital accreditation on quality measures: an interrupted time series analysis. Health Services Research, 12(137), $1-14$. https://doi.org/10.1186/s12913-015-07845

Fitriati, R., \& Rahmayanti, K. P. (2012). Government Support in Triple Helix Collaboration to Provide Health Service Delivery: Case Study Government Hospital in Bengkulu Hospital ," 52, 160167.

https://doi.org/10.1016/j.sbspro.2012.09.4 52

Harus, B. D. A. S. (2015). Pengetahuan Perawat Tentang Keselamatan Pasien dengan Palaksanaan Prosedur Keselamatan Pasien Rumah Sakit Panti Waluyo Sawahan Malang. CARE, 3(1), 25-32.

Jaiswal, N. (2016). A Study of Quality Systems and Its Effectiveness in $\mathrm{JCl}$ Accredited Hospitals at UAE, (10), 9-10.

Jumriani, A., Noor, N. B., \& Rivai, F. (2016). Faktor Yang Berhubungan Dengan Kinerja Perawat Dalam Implementasi Sasaran Keselamatan Pasien Di Rawat Inap Rumah Sakit Stella Maris Makassar, 2016.

KARS, A. S. (2012). KARS Accreditation System.

Keles, A. W., \& Ch, G. D. K. (2012). Analisis Pelaksanaan Standar Sasaran Keselamatan Pasien di Unit Gawat Darurat RSUD Dr . Sam Ratulangi Tondano Sesuai dengan Akreditasi Rumah Sakit Versi 2012 Implementation Analysis of Standards Patient Safety Goals in Emergency Department Dr. Sam Ratulangi Tondano Hospital Accordance with Version 2012 Hospital Accreditation, 250-259.

KEMENKES RI. (2010). Peraturan Menteri Kesehatan RI No 1087 Tentang Standar Kesehatan dan Keselamatan Kerja diRumah Sakit. Standar Kesehatan Dan Keselamatan Kerja diRumah Sakit.

KEMENKES RI. (2012). Peraturan Menteri Kesehatan RI No 12 Tentang Akreditasi
Rumah Sakit.

KEMENKES RI. (2016). Peraturan Menteri Kesehatan RI No 66 Tentang Keselamatan dan Kesehatan Kerja Rumah Sakit.

KEMENKES RI. (2017a). Peraturan Menteri $\begin{array}{llll}\text { Kesehatan } & \mathrm{RI} & \text { No.11 } & \text { Tentang }\end{array}$ Keselamatan Pasien.

KEMENKES RI. (2017b). Peraturan Menteri Kesehatan RI NO 34 Tentang Akreditasi Rumah Sakit.

KEMENKES RI. (2017c). Peraturan Menteri Kesehatan RI No 40 Tentang Jenjang Karir Profesional Perawat Klinis.

Khaerunnisa Apriani. (2016). Gambaran Kejadian Nyaris Cedera Pada Pelayanan Kefarmasian.

Kitapci, O., Akdogan, C., \& Taylan, İ. (2014). The Impact of Service Quality Dimensions on Patient Satisfaction, Repurchase Intentions and Word-of-Mouth Communication in the Public Healthcare Industry, 148, 161-169. https://doi.org/10.1016/j.sbspro.2014.07.0 30

Lewis, J. A., Packard, T., \& Lewis, M. D. (2012). Managemen of Human Service Programs (5th ed.). United Stade of America: Brooks/Cole.

Lindawati. (2013). Faktor-Faktor Yang Berhubungan Dengan Persepsi Perawat Pelaksana Tentang Upaya Pencegahan Infeksi Nosokomial di Ruang Rawat Inap Rumah Sakit Pusat Pertamina Jakarta, 2.

Meesala, A., \& Paul, J. (2016). Journal of Retailing and Consumer Services Service quality, consumer satisfaction and loyalty in hospitals: Thinking for the future. Journal of Retailing and Consumer Services, (October 2015), 1-9. https://doi.org/10.1016/j.jretconser.2016.1 0.011

Meliana, H., Anggraeni, R., \& Maidin, M. A. (2013). Determinan Kepatuhan Perawat di Ruang Rawat Inap Rumah Sakit Stella Maris Makassar. UNHAS, 1-11. Retrieved from repository.unhas.ac.id/bitstream/handle/12 3456789/10651/MELIANA HANDAYANI K11110329.pdf?sequence $=1$

Mitropoulos, P., Vasileiou, K., \& Mitropoulos, I. (2017). Journal of Retailing and Consumer Services Understanding quality and satisfaction in public hospital services: A nationwide inpatient survey in Greece. Journal of Retailing and Consumer Services, (July 2016), 0-1. https://doi.org/10.1016/j.jretconser.2017.0 3.004

Mohebifar, R., Hasani, H., Barikani, A., \& Rafiei, S. (2016). Evaluating Service Quality from 
Patients ' Perceptions: Application of Importance e performance Analysis Method. Osong Public Health and Research Perspectives, 7(4), 233-238. https://doi.org/10.1016/j.phrp.2016.05.002

Notoatmodjo, S. (2010). IImu Perilaku Kesehatan (1st ed.). jakarta: Rineka Cipta.

RI, K. K. dan I. (2012). Sistem Jaminan Sosial Kesehatan. Badan Penyelenggara Jaminan Sosial.

Rio Hardiatma, Arlina Dewi, A. L. (2015). Analisis Imlementasi Sasaran Keselamatan Pasien Dalam Menghadapi Akreditasi di Klinik Trio Husada Kota Batu, 14.

RSMP, P. (2017). Profil Rumah sakit "X" di Kota Palembang. Palembang.

Sabila Diena Rosyada. (2014). Gambaran Budaya Keselamatan PAsien Pada Perawat Unit Rawat Inap RSU Pasar Rebo.

Saraswati, G. (2014). Hubungan Supervisi Pelayanan Keperawatan Dengan Penerapan Budaya Keselamatan Pasien oleh Perawat Pelaksana di RSUP Sanglah Denpasar

Satria, W., Sidin, A. I., \& Noor, N. B. (2013a). Hubungan beban kerja dengan kinerja perawat dalam mengimplementasikan patient safety di rumah sakit universitas hasanuddin tahun 2013. UNHAS. Retrieved from repository.unhas.ac.id/bitstream/handle/12 3456789/5678/jurnalbebankerjadengankin erja.pdf?sequence $=1$

Satria, W., Sidin, A. I., \& Noor, N. B. (2013b). Hubungan Beban Kerja dengan Kinerja Perawat Dalam Mengimplementasikan Patient Safety di Rumah Sakit Universitas Hasanudin, 1-11.

Schmaltz, S. P., Williams, S. C., Chassin, M. R., \& Loeb, J. M. (2013). Hospital Performance Trends on National Quality Measures and the Association With Joint Commission Accreditation, 6(8). https://doi.org/10.1002/jhm.905

Setiyani, M. D. (2016). Implementasi Sasaran Keselamatan Pasien Di Ruang Rawat Inap RSU Kabupaten Tangerang. JKFT, (2), 59-69.

Setyarini EA, L. L. H. (2013). Kepatuhan Perawat Melaksanakan Standar Operasional Prosedur: Pencegahan Pasien Resiko Jatuh di Gedung Yosef 3 Dago Dan Surya Kencana Rumah Sakit BORROMEUS. Patient Safety 5.

Shafii, M., Rafiei, S., Abooee, F., \& Amin, M. (2016). Assessment of Service Quality in Teaching Hospitals of Yazd University of Medical Sciences: Using Multi-criteria Decision Making Techniques. Osong
Public Health and Research Perspectives, 7(4), 239-247. https://doi.org/10.1016/j.phrp.2016.05.001

Sundoro, T., Rosa, E. M., \& Risdiana, I. (2016). Evaluasi Pelaksanaan Sasaran Keselamatan Pasien Sesuai Akreditasi Rumah Sakit Versi 2012 di Rumah Sakit Khusus Ibu dan Anak PKU Muhammadiyah Kotagede Yogyakarta. Jurnal Medicoeticolegal Dan Manajemen Rumah Sakit, 5(1), 40-48. https://doi.org/10.18196/jmmr.5105.Evalua si

Tulus, H., Maksum, H., Studi, P., Manajemen, M., Sakit, R., Kedokteran, F., \& Brawijaya, U. (2015). Redesain Sistem Identitas Pasien sebagai Implementasi Patient Safety di Rumah Sakit Redesigning Patient Identity System as Patient Safety Implementation at Hospital, 28(2), 221227.

Ulva, F. (2017). Gambaran Komunikasi Efektif Dalam Penerapan Keselamatan Pasien ( Studi Kasus Rumah Sakit X Di Kota Padang ) Picture of Effective Communication in the Application of Patient Safety Fadillah Ulva STIKes Alifah Padang Email: dilla_afdal@yahoo.com PENDAHULUA. Pembāngunan Nagari, 2, 95-102.

Untachai, S. (2013). Modeling Service Quality in Hospital as a Second Order Factor. Procedia - Social and Behavioral Sciences, 88, 118-133. https://doi.org/10.1016/j.sbspro.2013.08.4 87

UU RI No 13. (2003). Undang-undang RI No.13 Tentang Ketenagakerjaan (pp. 1-50).

WHO. (2015). Panduan Kurikulum Keselamatan Pasien. (L. K. B. K. K. B. Kemuliaan, Ed.) (Multi Prof). Lembaga Kesehatan Budi Kemuliaan. Retrieved from http://www.who.int/iris/handle/10665/4464 1

Yulia, Sri, A. Y. H. (2012). Peningkatan Pemahaman Perawat Pelaksana Dalam Upaya Penerapan Keselamatan Pasien Melalui Pelatihan Keselamatan Pasien. Jurnal Keperawatan Indonesia, Volume $15,8$. 